City and Cosmology: Genetics, Health, and Urban living in Dubai

Dr Aaron Parkhurst

\title{
City and cosmology: genetics, health, and urban living in Dubai
}

(ID: 1398815 DOI:10.1080/13648470.2017.1398815)

Journal: Anthropology \& Medicine, Volume: 25, Issue: 01, pages 68 - 84. (Download Current

Citation: RIS BibTex)

Authors: Aaron Parkhurst (ORCID-0000-0002-0762-0929)

\begin{abstract}
In light of increasingly high rates of diabetes, heart disease, and obesity among citizens of the Arabian Gulf, popular health discourse in the region has emphasised the emergent Arab genome as the primary etiological basis of major health conditions. However, after many years of public dissemination of genomic knowledge in the region, and widespread acceptance of this knowledge among Gulf Arab citizens, the rates of chronic illness continue to increase. This paper briefly explores the clash between indigenous Islamic knowledge systems and biomedical knowledge systems imported into the United Arab Emirates. It presents vignettes collected from interviews and participant observation in Dubai as part of nearly four years of ethnographic research, completed as part of the author's doctoral work on 'Anxiety and Identity in Southeast Arabia'. Rather than radically informing health seeking behaviours among many UAE citizens, the emphasis on the 'Arab Genome' has instead reconfirmed the authority of Bedouin cosmological understandings of disease, reshaping the language that people use to engage with their bodies and their health. Local cosmology remains a powerful discursive element that often operates in contention, in sometimes powerfully subtle ways, with novel health initiative regimes. For many people in the region, genomic information, as it is often discussed and propagated in the UAE, shares an intimate relationship with ideas of fate and national identity, and sometimes serves to mitigate the increasingly uncertain terms of engagement that people share between the body, their health, and rapidly changing urban landscapes.
\end{abstract}

\section{Introduction:}

The underlying premise of this article extends from a simple, but profound anthropological critique in the practice of biomedicine in different societies. That is, when policy planners and health professionals try to think through ideas of behaviour change that 
accompany much of the discourse on obesity, diabetes, heart disease, and global health in general, they need to take into account people's perceptions or ideas of their ability to create bodily change for themselves in general. Medical anthropology has long emphasised the role of cultural landscapes and idiosyncrasies in producing powerful regimes of both illness and health, and alarming rates of chronic illness across the globe re-illuminate the systematic neglect of culture in policy planning and debate (Napier et al. 2014). How is agency constructed in "health seeking behaviour', and what are the wider social factors that inform 'health seeking behaviour'?

This paper is informed from long-term field-work in Dubai that focused on these questions of health seeking behaviours and how they relate to local ideas of fate, agency, and genes. Further to these ideas, however, Dubai provides a unique context to think through many forms of chronic illness that become propagated through individual habits and behaviours. From questions that emerge in my recent inquiries on the human body and urban environments, this paper explores an anthropological problem presented by the body in the city, namely, the disruption of the stable relationship between the human body and the environment. Genetics, as a concept, becomes an explanatory model that men and women in Southeast Arabia utilise to speak towards this disruption.

The ethnographic data used in this paper was collected as part of nearly four years of anthropological fieldwork in Dubai and Abu Dhabi, in which I lived and worked as an anthropologist (February 2007 - October 2010). It forms part of a larger body of work on the relationship between globalisation, chronic illness, and tradition within Southeast Arabia, undertaken as my doctoral research. The research was conducted in many social and medical spaces, but primarily in participants' homes, café's, and other intimate social spaces. Part of this ethnography was also conducted in clinical settings, involving participant observation in three mental health institutions (one in Abu Dhabi and two in Dubai), and two nutrition clinics in Dubai. My anthropological research began as a project studying mental health and the stigmatisation of mental illness in the Emirates, as well as men's health issues in the country in general. The current focus on diabetes and genetics emerged from concerns from both local health authorities and from Emirati lay persons. During my time in the Emirates researching chronic illness, Emiratis in general spoke often and openly about their engagement with genetics, and both their deep love and anxiety of the city. These themes comprise the focus of this paper. The research methodology consisted primarily of participant observation and interviews conducted in both Arabic and English. Unless otherwise stated, the dialogue presented in this 
paper was conducted in English. Most of the discussions between my participants and myself were qualitative, open ended engagements, though many interviews directed participants to discuss their understandings of genetics, the city, or both. Participants were recruited in a wide number of contexts: some participated in discussions as part of formal discussions in clinics; others were recruited through participant observation in Dubai, and we met in their homes, café's, or places of work in which I had access and permission to conduct fieldwork. Still others were part of a support network in my Arabic education. Most of the participants that inform the ethnography of this paper, and with whom I became close, were men. This is partly due to the nature of the overarching research questions on men's mental and physical health issues in the Emirates, but it is also due to the social structures of the country. While women participated in general interviews in public health spaces, I only had ethnographic access to men in more personal and private social spaces. The participants of whom this paper concerns are almost all Emirati citizens living in Dubai, with the exception of some perspectives from Euro-American health professionals working in the city. Citizenship in the UAE is still informed from tribal affiliation. Many Emirati in Dubai and Abu Dhabi are members of different branches of the Bani-Yas tribe, a large and powerful kinship group that enjoys a long history in the Arabian Peninsula. However, there are also many who trace their lineage through other large tribes. Emirati tribal leaders (sheikhs) often draw upon Bedouin identity in public discourse in Dubai, though the label of Bedouin is rather fluid. While different families in the Emirates have diverse historical backgrounds and histories that shape their experience of the developing Emirati cities, this paper draws upon shared understandings of the body and cosmology that unify the citizens of the Emirates.

Diabetes in the Emirates:

The predominant blood sugar disorder discussed in this paper is Diabetes Mellitus Type 2. This condition is categorised through the inability of the body to respond to insulin properly, and usually develops in adulthood. There are many risk factors that are known to contribute to Diabetes Mellitus Type 2, henceforth often referred to in this paper as simply 'diabetes', but most salient in public health narratives are those risk factors that correlate diabetes to obesity (Body Mass Index of 30 and higher), personal diets, behaviours, and habits. Diabetes is wellunderstood as contributing profoundly to a wide-range of co-morbidities. Because of its relationship with obesity, they are often discussed in unison by health officials in Dubai. 
The experience of diabetes in Dubai is often explained through narratives of 'energy'. Those who have the condition complain of not having any energy to go shopping, or go to work, and sometimes complain that they do not have the 'energy' to go outside, as the heat of Dubai's oppressive climate stifles them. This is especially frustrating for those who are told their condition is tied to inactivity. The experience of diabetes, however, is highly variable in Dubai, especially as the condition presents itself in increasingly younger individuals. It often first presents itself as a major problem when people have other ailments or are treated for other conditions. The experience of the condition remains confusing for many of the people with whom I spoke, especially for younger individuals (in their late 20 s or early 30 s). They were aware, and even fearful, of the cardiovascular risks that the condition informs, and they all had personally known others whose death at an early age due to cardiovascular disease was informed by diabetes. While they felt the physical effects of the chronic illness, and indeed, some had been diagnosed after an initial diabetic attack, their social lives, in their own terms, had yet to be grossly impacted by the disease. As a result, it was difficult for many people to narrate their current suffering beyond physical sensation. As I will discuss later, for many the condition was considered with some ambivalence. In this regard, when I spoke with people about the experience of living with diabetes, they often turned the discussion away from their own lives, and instead borrowed pathology as an opportunity to think through other aspects of their society.

Diabetes, and even obesity in general, is often seen by Emiratis in the UAE as a condition brought about by modernity. The Arabic term for diabetes in the Emirates is 'da3 alsuker' and translates literally as "disease of sugar." However, the Latin term 'diabetes' is used ubiquitously in both Arabic and English discourse. In this regard, its immediate relationship to food and drink consumption is disrupted, allowing for more fluid and complex understandings of the origins of the condition. Long-term medical professionals in the UAE remember and recognise the historical development of blood sugar discourse in the country. For example, a German physician who had practiced in the country for 20 years explained, "There was an idea, and I still come across this, that we [here he refers to himself, and other Euro-American expatriates] brought some of these conditions with us. Sometimes people might say 'you made this problem so you fix it', and I had no idea what they were talking about." The physician later came to understand that his patients were referring to the idea of Euro-American immigrants as perceived agents of disease, or at least associating these expatriates with the conditions of change and foreign influence that bring sickness. "My father thinks these things," a friend explained to 
me. "He thinks diabetes is a conspiracy from Israel or something like this." I asked why. "Well, people didn't have this problem, ... nobody used to have Diabetes. Or maybe they had it, I think, but nobody knew about these things. So they blamed everyone else. And now we know it is genetic, but even now some people don't believe that."

There is great complexity embedded in these ideas. Israel, here, is understood to be in partnership with American and European governments to subvert Arab society, though these ideas are not shared by everybody. There is also an attempt to understand how diabetes developed so quickly in the rapidly growing city. Other logics concern immigration as a direct process of pathology. In this regard, diabetes is seen less as something that develops from habits, and instead is partially socially constructed as something caused by ambiguous pathogens that accompany immigration. Others see Euro-American expansion as an agent of corruption, if not a direct agent of disease. The complex consequence of these commercial and social infiltrations on the human body is a trend seen in many areas of the world, and has been given the moniker 'cocacolonisation' (See Leatherman and Goodman, 2005). In the past, diabetes was not known to be a problem, and suddenly, one day it was. According to the International Diabetes Federation (IDF), during the culmination of my fieldwork, The Emirates had the second highest rates of diabetes in the world, behind the small Pacific island nation of Nauru (IDF 2010). This trend remains strong. Current data from the IDF holds that nearly 1 in 5 adults in the UAE is currently afflicted with diabetes, and the country's rates of diabetes are rising faster than both its neighbours in the Arabian peninsula and in the world at large (IDF 2015). If these rates continue, the prevalence of diabetes is expected to double within a generation.

My participants do not use the term 'cocacolonisation', but they are aware of these forces of commercial and social intrusions, and they see these processes centred in the city, namely, Dubai. My friend Ali, for example, spoke often about the problems that the city posed and the dilemmas it caused for him and his peers. Ali explains, "There are some people who just think it would be better if everyone (foreign) left, and there are other people who are afraid of what will happen if everybody leaves." "What do you think", I ask him. "I think like most people we love people to come here and we love to share our country. But maybe some people are meant to come live here, maybe some people should only come visit. Smaller is ok too, all these towers... It will be good to slow down, or else people (locals) will never leave their homes, and the people coming here will be bored, and they will stop coming... people are becoming very selfish.... 
[We] do not have to do much. We need to be better." At other times, he and his peers would complain about the fast food that they and their children consumed, or the amount of TV their family watched, always wildly gesturing to the streets. The city then becomes tied to indigenous understandings of modernity and disease, and is understood to be mapped upon the human body. The body and the city is, in many ways, still a developing subject of analysis in social science, though it has an emerging collection of thought in a range of disciplines from geography and anthropology to psychoanalysis. While architectural planning has throughout centuries borrowed upon human corporeality to understand the form of streets, buildings, townships and cities (see Vitruvius and De Vinci, for example), philosophers and artists near the beginning of the last century began to recognise the metropolis as a new grounding for human culture and corporeality (e.g. Mumford, 1934; "Metropolis", 1927). In a different vein, other thinkers in anthropology and geography conceived of the body and society as mirrors for each other (Douglas 1966), and the city, specifically, as a metaphor for the human body in which stable urban landscapes inform cultural understandings of the body and identity (Sennett 1996). In this way, space, place and the body become concretely joined. What Sennett identified is how urban spaces become normative, seemingly stable lived experiences for those who live within them. Yet, he also shows how this normative experience of urban-ness belies the reality of the city as a highly unstable, and profoundly fluid and dynamic space. It is a transformational entity in its own right that shares an anthropologically reciprocal relationship with the human body: the citycum-body is constructed by the body, much as people embody the dynamic forces of the city (ibid).

In discourse on diabetes, obesity, and heart disease, social scientists have long argued for a more holistic view of the body in relation to society to think through health seeking behaviour (see Edwards N. 2012; Farmer, P. 2005; Mendenhall, E. et al., 2010). Specifically, in order to create changes and shifts in health delivery and demographics, especially in a context such as London or Dubai, policy planners need to think beyond what a health authority might be able to issue, and think additionally about the pragmatics and lived experience of people as they try to move through their daily life. In terms of diet and exercise, this has implications for public transport, daily commutes, housing prices, and a wide range of socio-economic policy and practice. In this regard, city politics and urban management in the US and UK, for example, have informed urban neighbourhood demographics, the distances between an individual's work and residence, the pragmatics of daily travel, and opportunities to create and utilise time for activities beyond income production and household maintenance. These aspects of quotidian 
city life are mapped onto the human body in the form of chronic illness (Church et al., 2011; Cetateanua and Jones, 2014; Burgoine et al., 2014; Bourgois, 2006). The structural limitations of urban living often provide daunting hurdles to prevention of chronic illness, but there is a psychological aspect to health behaviour and practice that is sometimes ignored. That is the sense of futility many people express and experience in thinking through how they might work upon their bodies.

\section{Diabetes and Fate}

Obesity and diabetes are made complex in Dubai, as they are medical categories that are often fraught with ambivalence, and they are not always seen as unhealthy body categories in the city and country at large. This is certainly not unique to this region of the world (see Randall 2011, or Popenoe 2003, for example). One of the issues that contributes to high Body Mass Index and high rates of blood-sugar disorders in Southeast Arabia that is not discussed in this paper is the perception of these conditions as normative or healthy, and in the case of obesity, sometimes desired. However, as discussed in the section above, diabetes, specifically, is often understood as a condition of modernity, a sudden product of 'modernisation'. This is evidenced by my participants in a number of ways. One concern from locals is the idea of Western imperialism as an agent of disease. The widespread idea of diabetes in the region grew in similar terms to the influx of foreign immigration, products, and ideas. This type of modernity also brought more robust systems of medicalization into the country. Very few in the Emirates were diagnosed with diabetes before the invitation towards foreign development, and so it is rather reasonable to deduce that it is a 'Western' illness category that expatriates brought (and continue to bring) into the country. This perception is made complicated by discourse that links Western material and social imports to cultural pollutants, if not direct agents of disease. American designed fast-food industries, expensive villas, sport-utility vehicles, mass media, and even increased longevity become objects vacillating between desire and danger. All these vacillating objects were tied to urbanising processes, and the city is perceived to be the locus of these goods. In this regard, the desert was often looked upon as a safe haven. As one of my participants proudly advertised, "I make my family go camping to the desert every month usually because it is the best thing to grow up right... It is like a medicine." Though, even then, my friend's 'tent' was fitted with modern amenities. Vacillation, as theorised by Ghassan Hage (2010) 
"occurs because we do not always know what we want and we often want contradictory things... we can say that vacillation is when there are many incompatible things giving meaning to our lives and we find ourselves pursuing them despite their incompatibility. What is important, though, is that vacillation is not just a movement between various states of being; rather, it is a state of being in itself' (Hage, 2010:152).

My participants often describe themselves in this way, torn between desires for conflicting interests and identities. Some defined the city as "a place where people don't know how to not want things." The desire for both modernity and tradition, and the perceived futility of pursuing both, creates conditions of uncertainty that my participants expressed often. The city becomes a vessel for this uncertainty, and becomes tied to other categories of ambiguity more closely associated with the body; namely, genetics.

As Kilshaw has demonstrated in her ethnography in Qatar (Kilshaw 2015, this issue), the Qatari state's dedicated mission to become 'modern' borrows significantly on the role of genetics, but this is often in contention with the way that local Qataris "themselves understand and incorporate genetic knowledge into their lives" (Kilshaw, this issue). Institutionalised genetic sequencing and testing programmes speak towards a local desire to bring Qatar forward as a global leader in healthcare, and they become representative of a 'modernity' of which Qatari citizens are very proud. Yet, balancing these desires with traditional emphasis on inheritance makes genetic dissemination very complex, and in some ways, ironic (Kilshaw 2015, this issue). In the context of Dubai, the imports described above bring both comfort and 'corruption', and are problematically, though not necessarily falsely, tied to conditions that are often ethnographically also attributed to genetics, such as 'misbehaving children' (in terms of autism spectrum), depression, and, saliently, diabetes. All these categories are, then, often understood as diseases brought by the West. Some speak of diabetes as a result of a loss of traditional value and culture or religion. For example, I met a participant who insisted that soft drinks, and specifically Coca Cola, were ruining the health of the city (indirectly invoking the idea of cocacolonisation discussed above), which is something he and I agreed on to a degree. He asserted, however, that if locals drank more coffee, as was considered traditional, then the diabetes epidemic could be annihilated. There may be some medical truth to this, depending on the ways and the amounts coffee is consumed. However, my participant's concern was not with the physical and chemical properties of the drink. The harmful long-term effects of soft drink 
consumption are not always perceived to stem from the ingredients of the products: sugar, corn syrup, or, perhaps, colouring compounds. Rather, it is the nationalism of the product, and its cultural disruption that is understood to be poison for the human body. 'Cocacolonisation', then, is a useful but limited concept in the region as it directs analysis of health seeking behaviour away from the individual and places it within wider systems of structural imbalance. My participants do often recognise that coca-cola, as a 'material', leads to Diabetes, but this 'material' takes on different meaning depending on its source. In this regard, sugar is good when it is used to make local products, and bad when it is imposed upon those who fall within Euro-American patterns of consumption.

Parallel to local understandings of foreign influence are increasingly prevalent public discourse on genetics. Within popular imagination, there is a widely-held perception of genetics as diabetic aetiology; that is, genes are largely, if not wholly responsible for diabetes. For example, where I was discussing aetiology with one of my participants, I was speaking about genetic susceptibility for type 2 diabetes, a 'gene' for diabetes, and he was speaking of 'Al Djinn', those ambiguous agents of the desert, usually frustratingly amoral, that are known to influence the world of humans and disrupt human agency. I am careful to note that he probably does not mean this literally, that genes and Djinn are one and same. Or, if he does, it remains speculative. However, in many regions of Southeast Arabia, genes and Djinn, as ambiguous categories of nature and fate, do borrow each other's language, if not further synonymy. It is a recognition that the sands and vastness of the Rub al Khali, the vast desert that lies across the Southeastern Arabian peninsula, and the human body were both their own cosmologies, populated by cosmological agents that can affect one's life and well-being.

In this way, genes have been incorporated into indigenous cosmology. The language and rhetoric that my participants apply to discourses of fate are often re-appropriated to help them think through genetics and other biomedical body knowledge. While I do not have the space in this paper to unpack the complex construction of 'fate' itself in Dubai, my larger ethnography has shown that fate is a language of uncertainty in Dubai, but is often incommensurable and sometimes even congruous with deep personal agency (Parkhurst 2014). In thinking through the body in the city, and the body of the future, fate becomes a rhetoric that is helpful to situate oneself in the conditions of vacillation I have described above. In relationship to disease, other anthropologists have shown how Islamic conceptions of fate are better understood as languages for structural imbalance. Sherine Hamdy's work in Egypt, for example, shows how fate is 
invoked by some as mechanism to take action and meaning within systems of political failure and structural violence (Hamdy, 2008, 2009). In contrast to traditional perceptions of 'Islamic fate' by colonialist thinkers, my participants often invoked strong sentiments of personal cultivation and cosmological futility simultaneously. Because of its place in religion and other systems of social relations, fate, as locally defined as submission to God, is proudly locally owned as a marker of identity, yet is practiced with ambivalence. Processes of modernity and urbanisation as understood by my participants, because of their own ambiguity, and because of their association with bringing both success and disease, are then placed within this language of fate. As genes become increasingly understood as carriers of both identity and disease, they become tied to these languages as well.

The development and dissemination of molecular biological science in laboratory cultures over the last five decades informs the social understandings of genes as the science is imported into new contexts. Outside of the Middle-East, this trend has provoked wide philosophical and bioethical debate. In discussing genes with patients, or the public, an oftenoverlooked consequence is a lay understanding of genes as destiny. Within the scientific community, this problem has been discussed for decades, asking, in a broader sense, what it means to say ' $\mathrm{x}$-gene determines $\mathrm{y}$ '. Richard Dawkins has fought against this type of genetic deterministic understanding, asking, "Why are genetic determinants thought to be any more ineluctable, or blame-absolving, than 'environmental' ones?” (1999:10-11). There is, arguably, a cultural miscommunication here between the cultures of laboratories and the general public. For many philosophers, and laypeople, the question is somewhat teleological, for biologists, the question is statistical (ibid). Nonetheless, the human body, as it ambiguously weaves through all systems of social relations, blurring biology and culture, remains a steadfast anthropological problem (Csordas, 1994; Scheper-Hughes and Lock, 1987), and genetics, understood as synecdoche for the body, have only complicated long-running debates on what it means to 'be in the world' (Franklin, 1995). Ethnographically speaking, genetic understandings can be strikingly and profoundly meaningful, and have the potential to elicit powerful change in individual and social identity (Rabinow, 1996). Anthropologists, recognising the need to create new theoretical tools to think through the ramifications of genomic information in society, have taken on-board this concept of 'biosociality' to help understand the role of genes within ethnography (see Gibbon and Novas, 2008). However, they are also critical of instilling too much power within the gene as definitive instruments of change and control (Rabinow, 2008). Within the clinic, semantics of genes can radically inform patient behaviour, in both informing aetiology (see 
Senior et al., 1999 for example), and, in new ways, avoiding aetiology (Franklin and Roberts, 2006). Within larger debates in anthropology, these disruptions of nature and culture perhaps provide evidence for the post-modern viewpoint that social science itself has ill-constructed binaries which it debates and refutes (Latour, 1993). Molecular biology may have a role here as well. New genetic sciences and epigenetic influences on the body contribute to the development of radically new debates within anthropology on nature and culture (Lock, 2012, 2015). However, it is worth noting that, for the people within the context of this study, the line between the biological and the social has always been very weakly drawn. The people of Dubai do recognise genes are biological agents, but they are simultaneously social ones, as I will discuss.

How people construct the notion of fate, or destiny, in relation to genes, is just as delicate as social and biological binaries. The language of genetics, premised on imaginations of the inevitability of nature, remains an instrument that can invoke a sense of fate, or a prescription of behaviour. This is further complicated by deeply held values of genetics as specifications of race, and by extension, ethnicity (Fullwiley, 2007). As I have argued elsewhere (2014) one implication here is that many geneticists still wantonly operate under the same formulas for 'national character' that social sciences have accused the Orientalists of perpetrating, and that scholars have attempted to weed out of anthropology. In this way, the semantics of genes are translated outside of the laboratory to the public to give chemical and organic evidence towards national identity.

In the Emirates, the relationship between genes and national identity often takes complex forms. While there exists a robust local knowledge of the mechanisms of inheritance and kinship in Southern Arabia that I have not the space to discuss in depth here, genes as biological entities are not necessarily part of, and not always associated with this inheritance and kinship. Genes are widely known as identity markers independent of kinship. They are widely known to be carriers of disease, but are not generally understood to contain the essence of, or the benign traits of, a person. The following brief conversation between myself and two of my participants, a debate on the genetic influences to, say, hair colour vs diabetes, illustrates local incommensurability between genes and inheritance. It began from a popular discussion among my participants - what makes a person beautiful.

\footnotetext{
(Ali) "A woman's hair comes from her mother, and that is why they are keeping it like this [silky, and pitch black]."
} 
(Myself) "What about diabetes", I asked, "is this something that comes from the mother or from the father?"

(Ali) "No, this one is genetic I think."

(I continued) "Sure, but do you get it from your mother's side of the family, or does it come from your father's side of the family?".

(Ali) "No, these ones, these diseases they are genetic."

(Myself) "Fine, but where does it come from?"

(Ali) "No, yaani, they do not come from anywhere. I am trying to tell you that. They are not coming from anywhere."

(Myself) "But if they are genetic, they are inherited from someone!"

(Ali) "Yes, but no it does not come from anywhere, yaani, this is why it means it is genetic"

(Myself) "Well, what does genetic mean?"

(Ali) "It means that you have genes... that it is because you are Arab or maybe like these people", he points to a group of Filipinos who were working at the café in which we met.

(Myself) "[The Filipinos] are genetic?", I asked. The two men at the table could see that I was confused.

(Rahman) 'Don't you know that Arabs have these genes and that British people have these genes and all these peoples have these genes.", one of them yells at me.

(Ali) "He means different genes", his colleague explains.

(Rahman) "Yes, yaani, different genes all these people," he clarifies.

(Myself) "Yes, I understand that, but where do these genes come from?"

(Ali) "But they are not coming from anywhere is what I am telling you. They are because they are these people... ." His friend interrupts,

(Rahman) "We are Arab so we have some of these ones [genes]."

(Myself) "Is being Arab genetic then?”, I asked.

(Rahman) "Yes, of course, and like you are coming here from England."

(Myself) "Is being English genetic?"

(Rahman) "Yes that is what we are trying to tell you."

(Myself) "Ok, so is being Emirati genetic?". This question seemed to provoke some thinking. After a short time, they answered.

(Both) "No, this one is not genetic, it is coming from who your father is."

The debate continued for some time. I asked about skin (from the mother), height (from the father), obesity (genetic), cancer (genetic), eyes (mother), gender (father), and so forth. I continued these questions with many people throughout my fieldwork, with more or less the 
same responses. In terms of pathology, diabetes, cancer, obesity, and both psychotic and nonpsychotic mental illness: these conditions and behaviours were perceived to be genetic. However, certain types of nationality and general behaviour, and the phenotypic attributes of appearance were said to originate with parents, in the home, and in the womb. Ethnicity, as a concept, and as a broad signifier, is often slippery. Being 'Arab' or Chinese, or White-European, in local terms, was discussed as evidenced through genes. Being Emirati, for example, is inherited, but not genetic, while being Arab, and more specifically, deriving from Southeastern Arabia at large (Bahrain, Qatar, Emirates, Oman, possibly Saudi, but not Yemen) is said to be informed through genetics. Beyond biology, many factors contribute to these designations: Bani-Yas tribal affiliations, ties to desert and coastal landscapes, concepts of wealth, constructs of purity, and language practices - but to name a few. While the limits of genetic influence in popular imagination provide further ethnographic evidence on the nature of agency in kinship and reproductive practices, the ambiguous coupling between pathology and ethnicity speaks to the constructs of genes in this paper.

John Avise, in his monograph on the Genetic Gods (2001), extends genetic determinism to the structural realm of cosmology, attempting to ask and answer questions that are, for many people, religious. The link between genes and gods can be, Avise argues, a rather rapid one. Certainly, as invoked in the anecdote above regarding AlDjinn diabetes, there is evidence for this in my field-site as well. Here, of course, the connection is not made with 'Gods', but it is still made with religious cosmological entities. This synonymy and parallelism presents an anthropological question: If genes conjure up their own cosmology within the imagination, then is it reasonable to suggest that an already present and strong cosmology might inform genetics? In the Arabian Gulf, genetics have found an audience with which it was unfamiliar. The intentions behind its language are especially vulnerable. The men and women of the Emirates already have a very robust and complex language of their own with which they can engage fate. Genetic dissemination was bound, in some way, to be reworked under these powerful Arabic articulations. There is not space here to do justice to the diverse and encompassing language of fate in the Emirates, let alone the Arab-speaking world at large, and despite the complexity of fatalistic discourse in the region, modern ethnography conducted in the Arabian Peninsula remains sparse. This paper in many ways takes the presence of fatalistic language as an ethnographic given, even if the link between behaviour and discourse is often nebulous and even sometimes careless (Chaves, 2010). 
In terms of how genetics and fate are interwoven in Southeast Arabia in general, other research has provided insight in contexts outside chronic illness. Kilshaw (2015) has analysed how maternal prospects, marriage and consanguinity highlights genetics and the management of risk in Qatari communities in and around Doha. Similarly, inherited blood disorders and genomic testing not only encroach upon marriage practice in Oman, but become novel signifiers of nationalism, history and identity in a context in which normative concepts of time and history are politically prescribed (Beaudevin, 2013).

The research presented here complements these works. Rather than simply replace the cultural models of the world that the Bedouin and coastal tribes of the UAE know to be true, foreign medical and scientific concepts are re-shaped and interpreted through the languages of the desert, themselves becoming common discursive elements of public knowledge. In thinking through 'genes' as agents of disease, and Djinn as ambiguous spirits of the desert, my participants see congruences. The slippage between Djinn and genes becomes a powerful metaphor to depict the fallacies inherent in the designs of globalization and in the assumptions embedded in Western scientific empiricism and dissemination. The direct association between these terms is not as important here. What I argue is that the failure to recognise genetics as its own cosmology can indeed perpetuate suffering. I have argued that Emirati conceptions of the self and body in relation to nature, spirits and foreigners are challenged by the promises of globalization and modernity. As people move through the desert, the coast and the rapidly growing cities, their quest for an elusive notion of modernity ricochets into local systems of destiny, cosmology, agency, body practices, and kinship, and the languages one uses to articulate the 'self' and world are transformed.

The language of fate is a language in which genetics is often fully embedded. As discussed, while the epistemology of 'genetic determinism' has been a trope borrowed in both social and biological landscapes in the West, fate is far more culturally owned in the Gulf, and in much wider social ways than in, say, the UK. Ideas of Islamic fatalism are often a proudly culturally owned category in the region. As Bourdieu has told us of the Kabalye, "Submission to nature is inseparable from submission to the passage of time scanned in the rhythms of nature" (Bourdieu, 1963: 57). Bourdieu was attempting to understand fate, fatalism, or determinism among his Islamic informants in Algeria. In his writings, his informants understood fate as scanned in the rhythms of nature. This is not foreign to my participants who invoke a similar symbolic association with nature, and specifically the moon, the tides, and even genes. However, 
these terms are variable in meaning for my participants depending on the context in which fate is invoked. I have argued elsewhere (2014) that 'Islamic fatalism' in the Gulf is often a poor concept. Rather than see themselves and their fate inescapable from the moon or the tide (as James Fraser (1990) has poetically described a century ago), I struggled to find notions of Islamic fatalism in common practice, and in the reality of people moving through their day. Rather, nature was a stable stage in which people took comfort. The coast, tides and waves, and above all, the desert, provided a language of empowerment, that the individual could effect change in the world, and should indeed do so. Oil provided an index of power that was granted from nature, and Bedouin reliance of the ever-stable Earth reinforced these motivations for planning, hurrying, scheming and creating - at least among the Gulf's elite. Bourdieu's Algerian notions of fate and hubris do exist in conversation and song, but they usually contradict practice.

Chronic illness in Dubai, and specifically diabetes, complicates applications of fate. Many of my participants, and especially young and middle-aged men, understood diabetes as something within the body that can make one sick, but not as a constant condition in and of itself. In times of diabetic distress, patients would eagerly seek immediate medical attention, and then participate in health planning in the few days and weeks following their distress, though these behaviours would generally transform into old habits. It was difficult for many participants to imagine themselves being ill in those times in which they did not feel ill, and indeed felt normal. It is in these contexts that the language of fate and genes were simultaneously invoked.

In these ways, I have briefly outlined how genes in the Emirates become simultaneously tied to pathology, race, ethnicity, and fate. These relationships are made evident in local discourse in complex ways. Consanguinity, in the Emirates, for example, is increasing. Studies indicate that slightly over half of Emirati marriages are consanguineous (Al Gazali et al., 1997). However, as the local population increases, and as the Emirati population has more access to education and health services, the rates of consanguinity have increased. Contrary to patterns in many other parts of the world, in the span of one generation, research indicates that rates of consanguineous relations have risen another 10\%, and the preferred marriage is between first cousins (ibid.). Studies in the Emirates have attempted to examine the effects of the trends in these marriage practices on health patterns (Tadmouri, 2009; Abdulrazzaq et al., 1997; Al Gazali, 1995). However, new local understandings of genetics give novel meanings to inheritance. Paired with traditional ideas of fate, and tied, again, to anxieties related to an ever-increasingly heterogenous city, genetic information, for many, may ironically help inform higher rates of 
consanguinity. Similarly, Kilshaw has collected narratives of women in a similar context in Qatar in which dialogue between genes, responsibilities towards health, arranged marriages, and familial obligations are constantly contested and negotiated (2015, this issue).

Chronic illness presents similar challenges. Chronic illness is, by its nature, confusing as negatively constructed pathology. If disease in general can be discussed through fatalistic terms, chronic illness, for which patients may not recognise or anticipate future symptoms, becomes even more of a logical consequence of destiny. Race is constructed in Dubai as a profoundly positive form of cultural capital, and genes as markers of race are proudly owned. In other aspects of social engagement, many are very protective of what is acceptable as informed by genetics. Mental illnesses are often said to be genetic, but sexual behaviour is not, and my participants become deeply offended at suggestions that sexual behaviour might be informed from biology. When race, seen as a profoundly positive social capital, is made parallel to pathology in terms of genetic dissemination, an individual's natural approach to their chronic illness often becomes marked by indifference, and on some occasions, might even be embraced as a socially owned form of cultural capital, regardless of the health consequences. As a result, emergent public genetic education on the 'Arab' genome, designed by health authorities to curb those habits that encourage and spread chronic illness, is local embraced as authoritative knowledge, mirroring the language of fate that local residents have long used to articulate their world. However, as authoritative as the concept of the gene in the Emirates is, it fails to produce the behaviour change for which health planners have hoped. Indeed, the opposite effect has occurred, as the rates of diabetes and obesity continue to climb.

\section{The Body and the City}

The 'city', however, creates a new and very real dilemma for those who inhabit them, and it has ramifications for the body. In my previous fieldwork, I set off to answer a very broad question in the Emirates: What happens to identity within indigenous culture when faced with globalization and modernization on such a rapid course? Dubai, perhaps more than anywhere else in the world, is well suited to afford opportunities to explore this question. The city itself became a protagonist, and a type of an anti-heroine. In the years I lived in the city, I was able to watch megaliths rise from the sand. Countless workers from South Asia spun webs of steel and scaffolding from dawn until after dusk. Every evening the towers were half a metre taller. One can drive somewhere in the morning, only to be lost when the road is wiped away by evening. 
The city is a fortress against nature, a place that - even for my participants - could not be, should not be. For many of the residents of Dubai, the city is an impossible landscape, save for the vision of the sheikhs, and the blessings of God. Dubai, for many local people, is itself an articulation of their sub-conscious, arising from the dreams of their leaders who imagined the wealth of the city as they stared across what was once a tiny creek babbling along sand and rock. Because of this perception of Dubai as a materiality of local dream-scape, her betrayal is especially harsh. Many of the men and women who watched the first cargo come to Jebel Ali Port, and who remember the first hotels and towers, now feel that the city is designed for everyone except them. Some people act as if the city has its own agency, and there is a sense of amorality in its development, but for my participants, who are fiercely loyal to each other, to the sheikhs, and to Dubai, there is a sense that Dubai has not reciprocated, that at some point the city began to be disloyal.

The sand, the coast, and even the oil, previously dependable wells of wealth, gifted by the desert and the sea, that are worthy of their own ethnography (see Limbert 2010), are no longer the stable entities with which local people can pivot themselves against to enact identity. In this way, the relationship between people and their environment, as I have witnessed it in Dubai, becomes profoundly disrupted. Local Bedouin and Beni Yas tribal cosmology has long seen actors subject to the permanence of land and the inevitability of predictable - if sometimes oppressive - nature, the extreme reality of the desert, and the moon and tides in which they see the natural symbols of fate. The city, in this sense is profoundly disruptive. Cosmology which has longdepended upon a relationship between moving bodies and stable Earth fails to cohere in a landscape of rising monoliths, 14-lane highways, and an influx of cultures and languages from abroad, and, of course, genetic heterogeneity. Emiratis now compose less than 10 per cent of Dubai's population. No longer the flexible bodies against the rock, many people develop a deep anxiety which limits their ability for action across the gambit of individual and social enterprise. In other words, the uncertainty of 'modernity', whatever 'modernity' is, makes thoroughly intolerable the complexity of life's choices.

I have studied how this frustration over uncertainty becomes enacted in local cosmology, among the Djinn of the Emirates, who lash out against both the past and the future (2014). Here, though, there are repercussions for the body, which is, in the Emirates at least, one of the casualties in the conflict between local identity and the changing urban landscape. Fate becomes enacted uniquely here. Rapid change radically disrupts people's ability to see themselves in the 
future, and so 'health seeking behaviour' becomes desirable, but highly directionless. Genes, too, take on further meaning in light of the shaky ground. As a biological category of both fate and ethnicity, they are relied upon to provide an anchor to identity when identity is under threat from a newly uncertain world. They become a cosmology in and of themselves, synonymous with tradition, and their association with pathology is forgiven, and even valued as a consequence of fate. Health education directed towards managing and preventing chronic illness asks the individual to imagine one's body in the future. However, the body, as outlined at the beginning of this paper, is inexorably intertwined with the urban cosmos, and for many, the unstable, uncertain city makes this request for vision cognitively exasperating and disheartening. The city, as I have described, is a site of vacillation for my participants. They have called it, poetically, the "inescapable place of desire", highlighting their deep frustrations. My participants are not usually resentful towards the city. Indeed, they often express deep love for it along with their exasperation. They do not want to city to collapse, but they are simultaneously overwhelmed by it. Diabetes and genes becomes enmeshed in this exasperation, and many turn to concepts of fate to cope with their precariousness. Genes help concretise this fate within the human body.

\section{Conclusion}

I suggest as a final thought that both chronic illness and anxiety in the Emirates is partly the result of the ways in which many local people define what modernity means to them. Perhaps Dubai's betrayal is that it grew too quickly. Foreigners come to the desert and sift in and out of memory and landscapes, but it is the local Emirati who are left to make sense of the shadows of all this movement. Genes and Djinn, germs and fate, SUVs and oil, skyscrapers in the city, and the sands of the empty quarter all must be constantly reimagined, and it can be very arduous work. Emirati citizens value tradition and preservation, and they do want to preserve the new city. The task at hand is how paradoxically to create tradition and sustainability against a backdrop of something entirely new, but not just new, from something that has no firm foundation. Emirati locals do by and large know the steps they need to take for healthier lives, and they are educated on what health-seeking behaviours will drive communal health, but with both local imagination and local health structures, they lack novel frameworks in which these behaviours carry deeper meaning. For my participants, whilst their futures and their city sit upon volatile terrain, they hold steadfast to cosmologies that help anchor them to the world that they value, and they are fiercely proud of constructed Arab identifiers that help index their lives as both desert and urban people. Genes become valued as these identifiers, and are tied to 
conceptions of fate. Local people understand pathology when it is presented through genetic discourse, but in terms of the uncertainty of the city, and the threats the city presents to local identity, pathology becomes equally tied to fate.

The systems which inform rising rates of obesity and diabetes around the world are massively complex, and there is a host of social and biological factors that inform these body categories. My simple existential point is that when suddenly faced with the intensely myriad choices of the modern world, many people (regardless of nationality, religion, gender or race) simply, and ironically, cannot make any. This includes choices on health and habits. It becomes profoundly difficult to consider the future body in a landscape that wantonly clouds future vision. In the context of Dubai's rapid urban growth, residents rely upon structures of cosmology that they hold self-evident to cope with radical uncertainty, and they apply these cosmologies of the body and to emergent biomedical categories. In addition to health care education, and policy that addresses structural violence, in all its many forms, I argue that health-care planning and policy can still be profoundly informed by local cosmology, and it must take into account how the human figure pivots itself against a world that is, for many, no longer as sturdy and dependable as they once had known.

Acknowledgements:

This paper would not be possible without the participation and help from my informants in the United Arab Emirates, and I am grateful for the time they have given me. The author would like to thank the editors of this special edition, Susie Kilshaw, Sahra Gibbon, and Margaret Sleeboom-Faulkner for their reviews and suggestions that helped develop this paper. The author also thanks the anonymous reviewers for their helpful comments and edits. This paper is derived from research that was conducted with ethics approval from UCL.

Works Cited:

1. Abdulrazzaq YM, Bener A, al-Gazali LI, al-Khayat AI, Micallef R, Gaber T: (1997) A study of possible deleterious effects of consanguinity. Clin Genet, 51:167-173. PubMed Abstract OpenURL

2. Al Gazali, L I; Bener, A; Abdulrazzaq, Y M; Micallef, R; Al-Khayat, A I; and T. Gaber (1997) Consanguineous Marriages in the United Arab Emirates. Journal of Biosocial Science. Vol 29 (4), pp $491-497$ 
3. Al-Gazali LI, Dawodu AH, Sabarinathan K, Varghese M. (1995) The profile of major congenital abnormalities in the United Arab Emirates (UAE) population. J Med Genet 1995, 32:7-13.

4. Avise, John C. (2001) The Genetic Gods: Evolution and Belief in Human Affairs. Harvard University Press. Boston. (first published 1998)

5. Beaudevin, Claire (2013). Old diseases \& contemporary crisis. Inherited blood disorders in Oman. Anthropology \& Medicine, 20(2): 175-189.

6. Bourdieu, Pierre. (1963) 'The Attitude of the Algerian Peasant toward Time', pp. 55-72 in J. Pitt-Rivers (ed.) Mediterranean Countrymen: Essays in the Social Anthropology of the Mediterranean. Paris: Mouton.

7. Bourgois P. (2006). Lumpen Abuse: The Human Rights cost of righteous neoliberalism, City and Society; 23 (1): 2-12.

8. Burgoine T1, Forouhi NG, Griffin SJ, Wareham NJ, Monsivais P. (2014). Associations between exposure to takeaway food outlets, takeaway food consumption, and body weight in Cambridgeshire, UK: population based, cross sectional study. BMJ. Mar 13; 348:g1464. doi: 10.1136/bmj.g1464.

9. Cetateanua A, Jones A. (2014). Understanding the relationship between food environments, deprivation and childhood overweight and obesity: Evidence from a cross sectional England-wide study. Health \& Place Volume 27, May 2014, Pages 68-76

10. Chaves, Mark. (2010) SSSR Presidential Address: Rain Dances in the Dry Season: Overcoming the Religious Congruence Fallacy. Journal for the Scientific Study of Religion. Vol 49 (1), pp 1-14

11. Church TS, Thomas DM, Tudor-Locke C, Katzmarzyk PT, Earnest CP, Rodarte RQ, Martin CK, Blair SN, Bouchard C. (2011) Trends over 5 Decades in U.S. OccupationRelated Physical Activity and Their Associations with Obesity. PLOS One. May 25, 2011 DOI: $10.1371 /$ journal.pone.0019657

12. Csordas, Thomas J. (1994) Embodiment and Experience: The Existential Ground of Culture and Self. Cambridge University Press, 1994

13. Dawkins, Richard. (1999) The Extended Phenotype: The Long Reach of the Gene. Oxford University Press

14. Douglas, Mary (1966) Purity and Danger. Routledge. London 
15. Franklin, Sarah. (1995) Science as Culture, Cultures of Science. Annual Review of Anthropology. Vol. 24: 163-184

16. Franklin, Sarah and Roberts, Celia. (2006) An Ethnography of Preimplantation Genetic Diagnosis. Princeton University Press

17. Frazer, J.G., (1990). The golden bough. In The golden bough (pp. 701-711). Palgrave Macmillan UK.

18. Duana Fullwiley. (2007) Race and Genetics: Attempts to Define the Relationship. Biosocieties / Volume 2 / Issue 02 / June 2007, pp 221-237

19. Edwards N. (2012) Taking action on health inequities: Essential contributions by qualitative researchers. International Journal of Qualitative Methods. 2012;11:61-63.

20. Farmer Paul. (2005) Pathologies of power: Health, human rights, and the new war on the poor. Berkeley, CA: University of California Press.

21. Gibbon, Sahra and Novas, Carlos (2008) Biosocialities, Genetics and the Social Sciences: Making Biologies and Identities. London: Routledge.

22. Hage, Ghassan; 2010. Hating Israel in the Field. in "Emotions in the Field". (Eds) Davies, James; Spencer, Dimitrina. Stanford University Press. California. pp. 129-154

23. Hamdy, Sherine F (2009). Islam, Fatalism, and Medical Intervention: Lessons from Egypt on the Cultivation of Forbearance (Sabr) and Reliance on God (Tawakkul) Anthropological Quarterly. 2009; 82 (1) : 173-196

24. Hamdy, Sherine F (2008). When the state and your kidneys fail: Political etiologies in an Egyptian dialysis ward American Ethnologist. 2008; 35 (4) : 553-569.

25. International Diabetes Federation (2010) IDF Diabetes Atlas $5^{\text {th }}$ edition. Retrieved 04/04/17 from http://www.diabetesatlas.org/resources/previous-editions.html see also http://www.allcountries.org/ranks/diabetes_prevalence_country_ranks.html

26. International Diabetes Federation (2015) IDF Diabetes Atlas $7^{\text {th }}$ edition. Retrieved 04/04/17 from http://www.diabetesatlas.org/resources/previous-editions.html

27. Kilshaw S, Al Raisi T, Alshaban F. (2015) Arranging marriage; negotiating risk: genetics and society in Qatar. Anthropol Med. 2015;22(2):98-113.

28. Latour, Bruno. (1993) We have never been modern (trans by C. Porter). London, Harvester. Wheatsheaf. 
29. Leatherman, Thomas L.; Goodman, Alan (2005). "Coca-colonization of diets in the Yucatan". Social Science \& Medicine. The Social Production of Health: Critical Contributions from Evolutionary, Biological and Cultural Anthropology: Papers in Memory of Arthur J. RubelThe Social Production of Health: Critical Contributions from Evolutionary, Biological and Cultural Anthropology: Papers in Memory of Arthur J. Rubel. 61 (4): 833-846. doi:10.1016/j.socscimed.2004.08.047.

30. Limbert, Mandana (2010) In the Time of Oil: Piety, Memory, and Social Life in an Omani Town. Stanford University Press, 2010

31. Lock, Margaret. (2013) The Epigenome and Nature/Nurture Reunification: A Challenge for Anthropology Medical Anthropology: Volume 32, Issue 4, 2013

32. Lock, Margaret. (2015) Comprehending the Body in the Era of the Epigenome. Current Anthropology. Volume 56, Number 2

33. Mendenhall E, Seligman RA, Fernandez A, Jacobs EA (2010) Speaking through diabetes: Rethinking the significance of lay discourses on diabetes. Med Anthropol Q. 2010 Jun; 24(2):220-39.

34. "Metropolis" (1927) Dir. Fritz Lang [Film]. Universum Film AG, Germany

35. Mumford, Lewis (1934) Technics and Civilization, Harcourt, Brace \& Company, Inc., New York,

36. Napier, A David., Clyde Ancarno, Beverley Butler, Joseph Calabrese, Angel Chater, Helen Chatterjee, François Guesnet, Robert Horne, Stephen Jacyna, Sushrut Jadhav, Alison Macdonald, Ulrike Neuendorf, Aaron Parkhurst, Rodney Reynolds, Graham Scambler, Sonu Shamdasani, Sonia Zafer Smith, Jakob Stougaard-Nielsen, Linda Thomson, Nick Tyler, Anna-Maria Volkmann, Trinley Walker, Jessica Watson, Amanda C de C Williams, Chris Willott, James Wilson, Katherine Woolf. (2014) Culture and Health. The Lancet, Vol. 384, No. 9954, p1607-1639.

37. Parkhurst, AL; (2014) Genes and Djinn: Identity and Anxiety in Southeast Arabia. Doctoral thesis, UCL (University College London).

38. Pile, Steve (1996). The Body and the City: Psychoanalysis, Space and Subjectivity. Routledge.

39. Popenoe, Rebecca (2003). Feeding Desire: Fatness, Beauty and Sexuality Among a Saharan People: Fatness and Beauty in the Sahara. London: Routledge

40. Rabinow, P. (1996) Artificiality and enlightenment: from Sociobioloy to Biosociality. Essays on the Anthropology of Reason. Princeton, NJ: Princeton University Press 
41. Rabinow, Paul (2008). "Afterword. Concept work". In: S. Gibbon, C. Novas (eds.), Biosocialities, genomics and the social sciences; making biologies and identities. London: Routledge. pp. 188-193.

42. Randall, SC; (2011) Fat and fertility, mobility and slaves: long-term perspectives on Tuareg obesity and reproduction. In: Unnithan-Kumar, M and Tremayne, S, (eds.) Fatness and the maternal body: women's experiences of corporeality and the shaping of scoial policy. (pp. 43-70). Berhahn: Oxford.

43. Scheper-Hughes, Nancy and Lock, Margaret M. (1987). The Mindful Body: A Prolegomenon to Future Work in Medical Anthropology. Medical Anthropology Quarterly. Volume 1, Issue 1. Pages 6-41

44. Sennett, Richard. (1994) Flesh and Stone: The Body and the City in Western Civilization. New York: W.W. Norton

45. Senior V, Marteau TM, Peters TJ. (1999) Will genetic testing for predisposition for disease result in fatalism? A qualitative study of parents responses to neonatal screening for familial hypercholesterolaemia. Soc Sci Med. Vol. 48(12). Pp. 1857-60.

46. Spinoza, Baruch (1677) Ethics: Part III. Translated from the Latin by R.H.M. Elwes (1883). Public Domain. Retrieved Online http://www.ebooksbrasil.org/eLibris/spinoza.html

47. Stangroom, Jeremy (2005) What Philosophers Think. New York. Continuum International Publishing Group

48. Tadmouri, Ghazi O; Nair, Pratibha; Obeid, Tasneem; Al Ali, Mahmoud T; Al Khaja, Najib; Hamamy, Hanan A. (2009) Consanguinity and reproductive health among Arabs. Reproductive Health 2009, 6:17 doi:10.1186/1742-4755-6-17

49. Thrift, Nigel and Amin, Ash. (2002). Cities: Reimagining the Urban. Polity Press 